\title{
Sustainable Local Economic Development in Tanzania: Exploring Economic Challenges in Growing the Economy
}

\author{
Dr. Kaihula P. Bishagazi \\ Faculty of Economics and Business Administration, \\ Saint Augustine University of Tanzania (SAUT) \\ PO Box 307, Mwanza, Tanzania
}

Received: Oct. 24, 2020 Accepted: May. 14, 2021 Online published: May. 26, 2021

doi:10.5296/jpag.v11i2.15695 URL: https://doi.org/10.5296/jpag.v11i2.15695

\begin{abstract}
The failure of macro-economic policies to deliver meaningful reductions in poverty and achieve basic needs in Tanzania has provoked a deep questioning of the relevance of economic growth center policies in Local Economic Development (LED). The government and development partners are increasingly shifting from the traditional top down approaches to the all-inclusive bottom up approaches for effective local development. The concept of sustainable Local Economic Development is thus examined in the context of economic activities and challenges using a case study of Shinyanga region in Tanzania.
\end{abstract}

Keywords: Local Economic Development, Sustainability, Challenges, Local Government Authorities

\section{Introduction}

\subsection{Background}

The role of Local Economic Development (LED) for the economic growth of a country cannot be over-emphasized. It is regarded as one of the main catalysts of every nation's economy. In developing countries, LED is considered as a solution to unemployment, poverty, and income inequality. This is because LED is an active process that envisages a mutual relationship between local communities, local authorities and other relevant stakeholders so as to create local development that is sustainable (Kamara, 2017).

Despite its many achievements in the economic, political and social arena, Tanzania is still one of the poorest countries in the World where 44 percent of the population live on less than 
1 USD per day (World Bank, 2018). Moreover, there are significant inequalities between the rural and urban poor with 33 percent of the rural population living in poverty compared to 15 percent in urban areas (International Monetary Fund, 2018). This problem has persisted despite several efforts done by the government (Banyikwa, 2017). Most of the government's efforts involved macro-economic policies and economic growth center policies whose benefits bypassed small farmers, small-scale producers and traders who represent 95 percent of the businesses and contribute to more than 35 percent of the country's GDP (Wwuyts \& Kilama, 2014). Thus, a contemporary LED approach is increasingly seen as a viable alternative to traditional top-down development strategies which have largely failed to generate meaningful and sustainable economic development at the local level in Tanzania (Lyatuu \& Urassa, 2016).

Although the concept of LED has existed over four decades, it is still in an incipient phase in Tanzania and several efforts are being done to promote it. The government now recognizes that effective LED is community driven as well as Local Government Authority (LGA) supported (Olomi \& Gerwen, 2018). LED has only occupied a center stage in development discourse of the country recently and in 2016/2017, it became a formal national agenda whereby it was incorporated in the second phase of the national Five-Year Development Plan 2016/2017-2020/2021 (FYDP, Pg. 72-74).

Existing literature such as Akpeko (2018) has addressed challenges on the supply side only (i.e. the government's side) and very few studies in Africa such as Akudugu and Laube (2013) have identified LED challenges faced by the demand side (i.e. the local communities) and none in Tanzania. Parilla and Liu (2018) argue that sub-national economic development policy has undergone a recent shift from an almost exclusive reliance on supply side location incentives to stimulate investment to an approach that increasingly emphasize demand factors in the market as a guide to formulate sustainable LED policies.

Thus, to attain sustainability and to achieve the goal of becoming an emerging economy by 2025 , it is important for a developing economy like Tanzania to focus on identifying key local economic activities that sustain LED as well as key economic challenges that hinder it. In achieving this, this study uses the case study of Shinyanga region to identify and examine local economic activities and their respective challenges. Shinyanga region is selected because it has diverse of economic activities. Specifically, the region is not only one of the country's prime agricultural regions noted for production of rice, tobacco and maize (Deus, Magreth \& William, 2014); but also, among the leading regions in Artisanal and Small-scale Mining activities (ASM) (Mutagwaba, Tindyebwa, Makanta, Kaballega, \& Maeda, 2018). Due to this, local activities and challenges are easily evident. Moreover, there is a great potential for local economic growth if LED is properly addressed.

Particularly, this study uses a comparative approach between the two districts of Kahama Town Council (KTC) and Ushetu District Council (UDC) in order to obtain and capture detailed explanations for similarities and differences, to generalize from them and gain a deeper understanding of local economic issues in these districts. UDC and KTC are ideal for a comparative analysis because Ushetu DC has a rural character and a strong economic 


\section{Macrothink}

Journal of Public Administration and Governance

ISSN 2161-7104

2021, Vol. 11, No. 2

linkage to KTC while KTC is classified as a rural area with more urban inclination (i.e. rural-urban fringe). A similar approach has also been used by several researchers such as Meyer (2014) and Akpeko (2018).

Thus, the objectives of this study are three-fold: first, to identify the main local economic activities carried out at Kahama Town Council and Ushetu District Council; secondly, to identify the main economic challenges in doing business and in growing the economy at Kahama Town Council and Ushetu District Council; and thirdly to provide appropriate Public Private Dialogues (PPDs) recommendations for policy advocacy for sustainable LED at Kahama Town Council and Ushetu District Council.

This paper is addressed to policy makers and local government professionals responsible for influencing development policies as well as to LED researchers. The findings of this study will help policy makers when designing an appropriate system of LED interventions in Tanzania.

\subsection{Local Economic Development-A Broad Meaning}

\subsubsection{LED as a Concept}

Local Economic Development refers to the process in which local governments or community-based organizations engage to stimulate or maintain business activity and/or employment (Kacar, Curic, \& Ikic, 2016). The main aim of LED is to stimulate local employment opportunities in sectors that improve the community, using existing human, natural and institutional resources (Kamara, 2017). It involves the process of engaging local stakeholders and local authorities in partnership with national planning agencies and economic development partners to jointly identify, design and implement initiatives (i.e. exploiting the opportunities and resolving the challenges) aimed at stimulating the local economy (Pike, Marlow, McCarthy, O’Brien \& Tomaney, 2014). In essence this approach is supposed to mark a paradigm shift from the traditional top down approaches to the all-inclusive bottom up approaches for effective local development. Meyer (2014) provides an illustration of the service delivery triangle for Local Economic Development (LED).

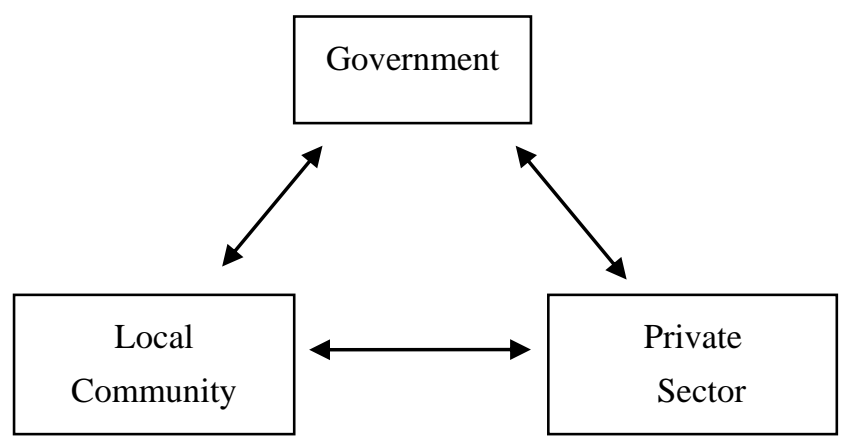

Figure 1. Service Delivery Triangle (Source: Meyer, 2014, pg. 626) 


\subsubsection{Sustainable Local Economic Development (LED)}

The value and success of local economic development can be considered in terms of "sustainable local development". This implies sustainable development of the quality of people, sustained reduction of poverty levels, structural transformation of the society in terms of politics, culture and economy which leads to greater productivity, income levels and choices for people and modernization of the economy (Bjarstig, 2017). The debates that exist around this topic have been explored and conclusions drawn by researchers such as Jovovic, Draskovic, Delibasic, and Jovovic (2017). It involves an exploration of all local economic development options available to the community and choosing those that mostly provide the most socially, economically and environmentally beneficial (or at least neutral) outcomes.

Bjarstig (2017) asserts that sustainability of local economic development in developing countries can only be achieved if it involves focusing on the poor; being culturally aware and encouraging participation from the bottom level. In summary, Jovovic et al. (2017) argue that both the existence of social capital and alignment between local organizations/stakeholders are key elements of success when aiming for the creation of sustainable local development initiatives.

\section{Related Literature}

\subsection{Theoretical Underpinning}

The concept of local economic development is associated with a number of established economic theoretical ideas. These include agglomeration economies, specialization and diversification, neo-classical growth, endogenous growth, and bottom up initiatives. However, the most relevant theories based on this study are the endogenous growth theory and bottom up theory.

According to Ansell and Gash (2018), endogenous theory assumes that increasing human capital and technological capability will induce economic growth as production becomes more efficient. The economic system of a locality will be self-sustainable as opposed to relying on external markets and inputs. Kacar et al. (2016) point out that the increase of capital mobility, trained workforce, information and other goods and services are not a first-rate basis for creating a rural development strategy. Instead, Hidayat, Glasbergen, and Offermans (2015) suggest that rural areas' advantages should be based on stationary resources that cannot be compared and contended. According to this theory, there are four types of stationary resources: social capital, cultural capital, environment as capital and the capital of local knowledge and skills. Economic development of rural areas will depend on the combination of tangible/material and non-material stationary resources, as well as on the way of their mutual relations in a local context (Dickovick \& Wunsch, 2014).

The bottom-up theory asserts that local people are a primary ingredient in the implementation and execution of local economic development strategies. These people and groups challenge traditional approach to decision making that comes from the top. This is especially important in poorer communities as a stable community base is required for people to acquire the resources they need, such as financial support, however, the sense of community is often 
lacking in the modern World (Kacar et al., 2016). The LED process aims to overcome this lack of community and instead reap the benefits that are possible from the bottom-up approach.

\subsection{Empirical Evidence}

Although there has been an increase in literature relating to LED in the past ten years in developing countries, empirical evidence on local economic development in Africa is still scarce. This is because, LED as an alternative approach to development, is a recent phenomenon and therefore less attention has been given to it in the local governance system.

The causes of local economic development in developing countries are yet to be clearly identified (Rogerson \& Nel, 2016). Nonetheless, Lyatuu, Nie, and Fang (2015) have shown that in low-and middle-income countries, poverty reduction at the local level is influenced directly as well as indirectly by agricultural growth. In his empirical study Agranoff (2012), found that the main causes of agricultural value added and rural household income growth identified are (a) macro-economic and political stability; (b) productivity enhancing new technology; (c) property rights and incentives; and (d) access to competitive inputs and product markets.

According to Owani and Mukuye (2018), a common challenge to LED is lack of reliable market to the agricultural produce. Akudugu and Laube (2013) advise formation of clusters of enterprises because if geographical concentrations of local producers are already in existence, then through joint action among local producers a new range of advantages can be created thus strengthening competitiveness of clusters.

Another challenge to local economic growth involves low productivity. Empirical evidence by Rogerson (2011) shows that the great majority of households in rural areas in Africa live from subsistence farming. The district enterprise is rather small whereby most enterprises operate in the informal economy where working conditions are poor and productivity is low (Rogerson, 2011).

In addition, Akpeko (2018) found that bureaucracy in starting a business is a common problem in most of LGAs in Ghana. Similarly, Khumalo (2015) concluded that the governance system in South Africa is rather complex as various layers of the government intervene in private sector development at the local level. Consequently, entrepreneurs have to obtain permits and licenses from different agencies or departments where the controlling function often prevails beyond client orientation.

Poor availability of extension services is also a challenge that faces many LGAs in developing countries (Akudugu \& Laube, 2013). According to Selmeczi (2015), the success of the innovating farmer depends also on the presence and efficiency of supporting services such as extension services. Khumalo (2015) adds that peasant farmers in areas where systems are in existence have a better chance of economic survival than peasant farmers in areas where they do not exist.

The level of business management and technical skills amongst local entrepreneurs in most 


\section{Macrothink}

Journal of Public Administration and Governance

ISSN 2161-7104

2021, Vol. 11, No. 2

LGAs is not very high (Kamara, 2017). Apart from that, Small Business Administrations (SBAs) are often not very strong in delivering services to their members and voicing their interests (Meyer, 2014). This contributes to lack of dialogues between public and private sectors. Apart from that, local people tend to have a negative bias towards business and enterprise, which they consider too risky and/or exploitative. This was found as one of the main local economic challenges of Micro, Small and Medium Enterprises (MSMEs) in UMlalazi local municipality in KwaZulu-Natal in South Africa (Jili, Masuku \& Selepe, 2017).

Moreover, according to Rickman and Wang (2019), suitable fiscal policies can cause a stimulation or a discouragement of local economic development. The importance of fiscal imperative for LED in developing countries has been stressed by several researchers such as Srithongrung and Sanchez-Juarez (2015). Despite that, many local economies are constrained by poor formulation of local fiscal policies (Owani \& Mukuye, 2018).

Lack of access to energy and more precisely to electricity in rural areas is one of the major impediments to local economic development (Torero, 2015) and this is substantiated by the study of Owani and Mukuye (2018). Beguerie and Palliere (2016) argue that a strong correlation exists between rural poverty and access to electricity because electricity is a pre-requisite for productive activities.

\section{Profile of the Study Areas}

\subsection{Kahama Town Council}

Kahama Town Council is strategically located between latitudes 30 15" and 40 30" South of the Equator and longitudes 310 30" and 330 00" East of Greenwich on the main road to neighboring countries of DRC Congo, Uganda, Burundi and Rwanda. By 2012 the population of Kahama Town Council was 242208 (117 498 males and 124710 females) with annual growth rate of 3.7 percent (National Bureau of Statistics, 2012). However, gold deposits in the district have attracted migrants from both within and outside of Shinyanga region and as a result, it is estimated that the current population of the area covered by Kahama Town Council stands at about 900000 .

\subsection{Ushetu District Council}

Ushetu District Council was established in 2013 after a split of the Great Kahama District to form Kahama Town Council, Msalala District Council and Ushetu District Council. The district is located in North-Western Tanzania bordering Kahama Town Council and Nzega District to the East; Msalala District to the North; Mbogwe district to the West and Tabora District to the South. The 2012 population census showed that Ushetu's population was 273 075 with about 67 percent of the total population contributing to the labor work force towards economic growth of the district. 


\section{Research Methods}

\subsection{Research Design}

Choosing the appropriate methodology for a study is said to be one of the most important decisions that a researcher performs in his/her undertaking. This study was designed based on the type of limitations that have been identified by previous researches dealing with government agencies, business owners and farmers. A qualitative research paradigm anchored the methodology of this study; however, elements of quantitative research were deemed appropriate thus forming a mixed method research structure.

\subsection{Data Collection}

Collecting data for this study was mainly structured around two approaches: primary data collection through semi-structured interviews and Focus Group Discussions (FGDs) (with the different stakeholders within both the government - Regional Administrative Secretaries (RASs), District Commissioners (DCs), District Executive Directors (DEDs), District Treasury Officers (DTOs), District Agricultural, Irrigation, and Cooperative Officers (DAICOs), District Planning Officers (DPOs) and the private - district officers of Tanzania Chamber of Commerce, Industry and Agriculture (TCCIA), farmers, livestock keepers, bee keepers, food processors, businessmen/women) as well as and secondary data desk reviews.

A total of two hundred and two (202) LED stakeholders were drawn from Kahama and Ushetu DC. The sample size was obtained using the Yamane's (1967, Pg. 886) formula (i.e. $\left.\mathrm{N} / 1+\mathrm{N}\left(\mathrm{e}^{2}\right)\right)$ at $10 \%$ confidence level. The Yamane's formula is preferred for finite population because it is simple and flexible whereby it allows calculation of sample size for a different combination of levels of precision, confidence and variability (Ajay \& Micah, 2014).

Table 1. sample size for KTC and UDC

\begin{tabular}{|l|l|l|l|}
\hline Name of the district & Sample size & male & female \\
\hline Kahama Town Council & 102 & 62 & 40 \\
\hline Ushetu District Council & 100 & 53 & 47 \\
\hline
\end{tabular}

Source: Field Data

The desk review encompassed a review of all documents provided by the respective LGAs and additional information that were obtained through online resources. Primary data were mainly collected from information-richest members of the desired population, who were selected purposively in order to generate reliable data. A database of the targeted stakeholders was obtained from the TCCIA-Shinyanga and the LGAs.

Face-to-face interviews were conducted between $8^{\text {th }}$ and $23^{\text {rd }}$ October 2018 with the selected key informants in Shinyanga, Kahama Town Council, and Ushetu District Council. Some questions were the same for all categories of the respondents and some differed according to the individual's responsibility and role played in the community. Interviews were also 
accompanied by transect walks in selected areas to witness firsthand how businesses take place. All interviews were conducted in Kiswahili and they were spontaneously recorded with the translation and transcription done later. This was done in order to ensure that no important information was lost in the course of the discussions.

\subsection{Data Analysis}

Qualitative data were analyzed thematically while quantitative data were analyzed descriptively. Financial and non-financial information was triangulated from the literature reviews, the interviews as well as from the focus group discussions. Apart from that, a data validation workshop was held in Kahama on the $6^{\text {th }}$ December 2018. It involved the District Commissioners (DCs), the two District Executive Directors (DEDs), LGA officers including Agricultural and Trade officers, farmers, traders, representatives of different Agricultural Marketing Co-operative Societies (AMCOS), financial institutions and TCCIA. The validation workshop helped the researchers to share study findings for stakeholders' validation and to obtain additional inputs from the stakeholders.

\section{Findings and Discussions of the Study}

\subsection{Main Local Economic Activities and their Challenges in the Value Chain}

\subsubsection{Agriculture}

Agriculture dominates the livelihood and economic performance of both Kahama Town Council (KTC) and Ushetu District Council (UDC). At KTC, the sector contributes more than 50 percent of the district's economy and employs about 40 percent of the working population thus representing an important local economic growth potential. Paddy alone accounts for about 40 percent of the council's total revenue per annum and therefore it is the one whose value chain is given the highest priority by the LGA. At UDC, agriculture accounts for about 60 percent of the LGA's total revenue tobacco being the leading crop in terms of district's revenue contribution on average accounting for more than 50 percent of the total revenue collected. Ushetu DC is a hub for tobacco production in the lake region, thus, it is the tobacco's value chain which is highly valued by the district. Apart from that, maize is considered important in both districts as both a food and cash crop which accounts for about 38 percent of the total planted area and is the leading crop in production accounting to 50 percent of the total production per annum. Other significant crops in both districts include millet, cassava, sweet potatoes, ground nuts, beans, cotton, sunflower, peas, grams, and horticulture.

Generally, agriculture plays an important role in the Tanzanian local economy and has the potential to advance the country's goal of being the middle-income country by 2025; and sustaining growth while reducing poverty. According to Lyatuu et al. (2015), agriculture employs around 63 percent of Tanzanians whereby 80 percent of them are smallholder farmers living in rural areas. Despite that, the value chain for agriculture is faced with a lot of local economic challenges, and the KTC and UDC are not an exception.

First, agriculture in both districts is dominated by smallholder peasants with very diminutive 
commercial inclinations. Hand hoe accounts for 90 percent of the implements used by farmers and only few farmers can afford hiring of tractors which costs about 13 US Dollars or Tshs. 25000 per $1 / 4$ of a hectare. Agricultural production in both districts is basically erratic depending on seasonal rains whereby there are two major rainfall seasons, with the long rains between March and May and short rains between October and December. Irrigation schemes are negligibly practiced by only 0.008 percent of the farmers.

Large scale farming is rarely practiced due to lack of reliable electricity. For example, D4N Ltd is the only potential large scale producer of rice with 1,100 acres at Marunga in Kahama TC. So far, the company has invested about USD 500 000/Tshs. 1 billion to construct an agricultural infrastructure including irrigation schemes, wells and dams for rice production. Unfortunately, despite such a huge investment, the company has no reliable power and uses a generator to obtain power for pumping machines which is not only very expensive to operate but also very inconvenient. Running a generator to power such a huge investment makes the project inefficient and will compel the promoters to sell their produce at high gate prices which may curtail market penetration.

In addition, the demand for agricultural inputs (like fertilizers) is very high although very expensive relative to the revenue collected from the sale of agricultural products. DAP, UREA, CAN and Agro folia are the most used chemical fertilizers for planting and growing crops with an average farmer requiring about 85 USD/Tshs. 170000 worth of fertilizers per hectare. Despite high costs, these fertilizers are not effective leading to low crop yields of only 20 percent. This is caused by both inadequate technical knowledge on the right usage of the inputs and a wide proliferation of the supply of fake/substandard agro-inputs in the region. According to the Confederation of Tanzania Industries (CTI) (2017), 60 percent of chemicals and 30 percent of seeds sold in most local areas in Tanzania are not genuine. A survey by SeedCLIR (Tanzania) in 2014 showed that only 15 percent of the seeds planted in Tanzania are registered and certified.

These challenges are exasperated by the existence of very few agricultural extension officers in the districts who cannot suffice to cater for the technical support needs of all farmers. Currently KTC only has 37 agricultural extension officers which is about 50 percent of the actual demand. In UDC, the LGA has the capacity to provide only 39 percent of the required agricultural extension services. Similar findings were revealed by Meyer (2014).

Apart From that, Similar to Meyer (2014), there is no organized marketing system for the agricultural products in both KTC and UDC. The market structure for farm produce is informal and under developed whereby 95 percent of famers sell their produce to middlemen who offer very low prices. This results to a low bargaining power for these farmers (Odwuro-Ofuri, 2016). For example, data collected from farmers show that on average, a tin of maize (about $20 \mathrm{kgs}$ ) is sold at 2.5 US Dollars/Tshs. 5,000 leading to a profit of only 0.075 US Dollars/Tshs. 150 per tin which is extremely low. For the case of tobacco, the prices depend on the grades. For example, in 2016/2017 there were 72 grades each with its own price with the highest grade (LIOF) being sold at USD 3.5/Tshs. 7,000 and the lowest (X6) at USD 0.5/Tshs. 900. Based on production challenges, it is not easy for the farmers to have 
higher grades and hence most of them sell the last grade tobacco (at USD 0.5/Tshs. 900). Given the operational inputs required, a farmer selling the last grade tobacco incurs a loss of about USD 2/Tshs. 4,000 per kilogram.

This challenge is intensified by lack of AMCOS or producer groups in the value chains of almost all crops within the two districts which is almost in concomitant with the general trend in Tanzania. A study carried out by Financial Sector Deepening Trust (FSDT) in 2011 revealed that only 14.3 percent of the agricultural producers are members of producer groups.

Generally, the most pressing challenge currently involves low productivity of smallholder farmers and weak linkages of market information from the farm level to the main consumer markets coupled with bureaucracy in export licensing, increased import charges on Tanzanian crops by neighboring countries such as Rwanda, Uganda and Burundi, and the decrease of the number of employees at the Buzwagi mine which has greatly decreased the demand for food crops such as rice in the area. Moreover, most small-scale producers do not have access to formal credit support. This finding is substantiated by a recent survey of Isaga (2018) which found out that only 1.9 percent of smallholder farmers in Tanzania have access to formal credit.

\subsubsection{Milling}

Kahama Town Council is the center for rice milling in Shinyanga region. It is estimated that 95 percent of the processing facilities in the district are milling machines mostly situated at Kagongwa township and Malunga. Eighty (80) percent of the rice millers in the district are of a medium scale who process about 600 sacks of paddy per day. Processing is done using both modern and traditional machines. Rice grading is also done at small, medium and large scales. There are basically three grades of rice produced in the district (i.e. grade 1, grade 2 and grade 3). Around half of the processed rice is exported to Rwanda, Uganda and Burundi. Other by products from paddy processing includes rice bran and maneuvering rice. On average, a medium scale rice miller obtains a profit of about USD 150/Tshs. 300000 from 30 tons.

On the other hand, milling activities in UDC are conducted on small scale due to lack of electricity which is a deterrent for medium and large-scale production and forces the processors to use diesel machines which are inefficient and expensive to run. Therefore, most traders depend on millers in Kahama TC for the medium and large-scale processing. Torero (2015) asserts that energy provision is crucial for local economies which are heavily dominated by the extraction of raw materials and primary processing. The International Energy Agency (2018) reports that only 65 percent of rural areas in developing countries have access to electricity, while rural electrification rate of transition economies is 99.9 percent.

In addition to that, the splitting of the Great Kahama D.C into three districts of Kahama Town Council (KTC), Ushetu and Msalala has greatly affected the revenue collection for KTC. As a result, the council has designed what are seemingly unfair bylaws against businessmen to maximize revenue collection from local traders. For example, some of the rice millers are 
charged two to three licenses for the same business as the LGA issues business licenses to rice millers based on a number of doors the processing premise has even if the business activity is the same! Therefore, if a miller has (for example) two front doors at his/her business premises, he/she is regarded as owning two businesses. In this regard, he/she will be required to pay for two hauling licenses each at USD 50/Tshs. 100000 per annum! Section 4(2) of the Business Licensing Act, 1972 (No. 25) provides a clear definition of an auxiliary business for which a second license should be charged and this definition does not include the number of doors as one of the criteria implying that this bylaw contradicts that Act. As a result of these unfair bylaws, trading activities have gone down by 12 percent and revenue collection has dropped by 5 percent and the situation could escalate if immediate actions are not taken to rectify these policies. Similarly, the local fiscal system of Gulu municipality in Uganda resulted to negative tax compliance and variance forms of avoidance schemes which led to the reduction of Gulu's contribution to the national GDP by 0.47 percent (Owani \& Mukuye, 2018). According to Srithongrung and Sanchez-Juarez (2015), LGAs' over-reaching role in local development is to provide an enabling environment for all its residents and businesses to prosper and this includes appropriate fiscal policies.

\subsubsection{Artisanal and Small-Scale Mining (ASM)}

Artisanal and Small-scale Mining (ASM) is a significant local economic activity mainly in Kahama Town Council. ASM has a great potential to contribute to sustainable local economic development (Desta, Bishagazi \& Temesgen, 2019). The main mineral deposit available in KTC is gold although there are also diamond deposits at Nyang'hwale also mined in small scales where large mining companies were operating in the past. ASM supplies an estimated 10 percent of KTC's gold revenue and provides around 20000 jobs in the district (Mutagwaba et al., 2018). With Buzwagi Mine heading for a closure, Artisanal and Small-scale gold miners are crucial stakeholders in the local economy of Kahama Town Council. Despite that, the ASM sector in KTC reflects poor local economic development performance. This is because of several local economic challenges facing its value chain.

First, it is an economic activity which requires heavy initial investment. For example, a typical initial cost of setting up a single mine pit would involve the following costs shown below:

Table 2. Estimated Initial Investment Costs for a Single Gold Pit

\begin{tabular}{|l|l|r|r|}
\hline s/n & Item & Cost (USD) & Cost (Tshs) \\
\hline 1 & Hut construction & 800 & 1600000 \\
\hline 2 & Wooden logs & 3,000 & 6000000 \\
\hline 3 & Extraction equipment (e.g. pickaxes) & 25 & 50000 \\
\hline 4 & Ropes & 50 & 100000 \\
\hline 5 & Pillars for ropes & 25 & 50000 \\
\hline & Total & 3,900 & 7800000 \\
\hline
\end{tabular}

Source: Field data

Besides the above costs the miners are also required to hire at least 10 people per pit paying 
their wages as well as catering for their food on a daily basis until the rocks with gold are found. On average, it takes between 3 months to 12 months of daily extraction before getting a sight of rocks with gold. These miners are forced to operate that way because they do not have geological reports which could help them to easily identify rocks with gold. Efforts to get access to these geological reports from government offices have so far not been successful. Often times, these miners end up not getting any gold despite having incurred such huge costs. Moreover, the Artisanal and Small-scale miners rarely get credit facilities by financial institutions as they are deemed to be engaged in risky businesses and they don't meet the borrowing conditions as set by the lending institutions.

Generally, the productivity per miner is extremely low (about 0.12 grams of gold per day) due to the usage of crude tools and poor technology. Extraction involves breaking and digging the rock by men using pickaxes and sledge hammers. Shafts can extend to depths of up to between 15 and 50 meters until gold bearing rock veins are found. Once rocks are broken from the rock walls, they are hauled to the surface where (for each 100 sacks extracted) the miners are required to immediately pay 6 percent of royalty fees; 1 percent as examination fee; and 5 percent as income tax regardless of whether they contain gold or not. The value for the charges depends on the auction price during that particular day.

After the gold has been extracted from grounded fine sand the miners are required to again pay for the second time 6 percent royalty fees, 1 percent examination fees and 5 percent income tax based on the value of gold extracted. The residue after gold has been extracted (also known as the "makinikia") are then processed into cyanide solution whereby any remaining gold will be extracted using 'Carbon In Pulp' (CIP) in illusion plants. The gold obtained from such process is charged for the third time 6 percent royalty fees, 1 percent examination fee and 5 percent income tax.

In addition to that, the Local Government Finance Act, 1982, gives the LGA the mandate to charge and collect 0.3 percent of the turnover as service levy. However, in 2017, without involving key stakeholders of the mining sector, the LGA passed a bylaw which requires mining processing plants to pay service fee at a flat rate of 7500000 per annum. Several plants have closed down because they have failed to pay this amount of service levy. This has led to a further loss of government revenue.

A similar study of Sosy (2013) concluded that the main economic challenges among local artisanal miners in Simanjiro district in Tanzania include lack of formal markets, lack of credit and poor technology. Zvarivadza (2014) in South Africa found that the main local economic challenges for gold Artisanal and Small-scale miners are: (a) lack of collateral security; (b) difficulty in obtaining information for planning purposes; (c) lack of education and professionalism; (d) failure to adapt to technological change; (e) and high grading. Similar conclusions were also made by Barreto, Echavarria, and Ruete (2018) in Karamoja district in Uganda for the gold ASM sector.

\subsubsection{Livestock Keeping}

Livestock keeping is an important activity for the majority of the households in KTC and 
UDC which supplements agriculture as an economic undertaking. Poultry rearing is the most significant livestock farming in the Kahama Town Council area. Unlike other districts in Shinyanga region, cattle rearing is not very significant in KTC because on the one hand, the Sumbwa, who are the dominant indigenous people of Kahama are traditionally not agro-pastoralists while on the other hand Kahama TC being an urban area, animal husbandry is practised by zero grazing whereby each household is allowed to keep a maximum of 6 cows.

Poultry farming at KTC is mainly dominated by chickens whereby 90 percent of the poultry businesses are small to medium scale producers who own between 200 and 2,000 chickens. There are several economic challenges faced by local poultry farmers. First, most chickens receive little or no animal treatments (such as antibiotics, wormers, vitamins and vaccines) which increases the mortality rates amongst the animals kept exhibited by immature deaths of a significant number of chickens. Moreover, hatching of eggs is the primary means of replenishing and increasing flocks' size. Although there are several available technologies, they are hardly used by producers due to the inadequacy in the availability of extension services and the low level of technical knowledge among most of the livestock keepers. There are only 16 qualified veterinary officers instead of the actual demand of 45 .

UDC, being a rural area, cattle rearing is the most significant livestock-keeping activity. Of all the cattle in the district 99 percent are of the traditional breed whose milk and meat productivity is low with low body weight of between $150 \mathrm{kgs}$ and $170 \mathrm{kgs}$ while a modern hybrid cow weighs between $600 \mathrm{kgs}$ and 1,000 kgs. Animal health and nutrition inputs are available at small private outlets in the district but they lack qualified veterinary officers. Extension services are weak as are most other services due to limited human resource and funding. Animal feeds are derived almost entirely from natural unimproved rangeland and crop residues. There are no formal markets for live animals in the district. Moreover, most animals are slaughtered at informal rural slaughter slabs because there are no formal abattoirs in the district and the meat is ferried to small butchers' shops in the villages and neighboring towns without any further value addition.

Prasanna and Shiratake (2014) found that the local dairy industry of Kurunegala in Srilanka is constrained by poor extension/veterinary services, low prices, and poor demand. Moreover, among other challenges, Addis (2019) found that seasonality of production, lack of milk collecting facilities, poor animal health management, inadequate supply of quality feed, low productivity and genetics, lack of processing plants, inadequate permanent trade routes and other facilities, prevalence of diseases, lack of credit and inadequate market information are dominant in the local dairy industry in Ethiopia.

\subsubsection{Beekeeping}

Beekeeping is another subsector which earns income to local people of both Kahama Town Council and Ushetu District Council. However, a business approach to bee keeping at a producer level is extremely low. In KTC, popular places for beekeeping activities include Wendele (Ngogwa) with 110 hives and Mwendakulima with 150 beehives with an average annual honey production in the council of $2,670 \mathrm{kgs}$ earning about US Dollars 5,000/Tshs. 10 
million. Unlike KTC, beekeeping in Ushetu District Council (UDC) is enhanced due to the availability of forest reserves such as Mpunze and Usumbwa. The annual honey production in UDC is about $600000 \mathrm{kgs}$. There are 40000 traditional beehives and 3,000 modern beehives in the district. Ushetu honey is popular due to its natural/organic nature and is demanded from as far as Zanzibar and Pemba, Rwanda and Uganda.

However, there are several challenges undermining beekeeping at a local level. First, 80 percent of beehives are traditional hives preferred by most local people because they are cheaper. However, these are disadvantageous as they significantly contribute to environmental degradation/deforestation and have got a low honey productivity capacity. The main reason for preference of traditional beehives is because of lack of financing mechanism to support beekeepers since the price of the modem beehives is higher for normal rural people to afford. Other threats to beekeeping activity include reduction of bee population due to loss of forests as well as conflicts over land use with herders and crop farmers, as well as heavy rains which curtail honey production.

Generally, both districts have not been able tap the full potential of this economic activity which has a readymade market with a great opportunity for large scale beekeeping because the current productivity level is unable to meet the current honey demand.

\section{Recommendations for Policy Reforms- Public Private Dialogues (PPDs)}

Sustainable local economic development cannot be easily achieved without joint efforts of both the public and private sector whereby the participation of non-state actors and demand driven, bottom up approaches are important. Thus, the local economic challenges addressed above should be resolved using the PPD approach. PPD is an institutional arrangement that brings together a group of public and private actors for joint problem analysis and identification of policies for institutional reforms that contribute to a more conducive environment for LED. At the local level, formal PPDs are carried out in District Business Councils for both KTC and UDC which were formed in August, 2018 chaired by District Commissioners (DCs).

Below is the recommended PPD Matrix that addresses local economic challenges identified during the study and key local stakeholders that are needed to solve them for each local economic activity. 
Table 3. The PPD Matrix

\begin{tabular}{|c|c|c|}
\hline $\begin{array}{l}\text { Local } \\
\text { Economic } \\
\text { Activity }\end{array}$ & Local Economic Challenges & Local Stakeholders for PPDs \\
\hline Agriculture & $\begin{array}{l}\text {-Low productivity which has not attracted } \\
\text { investment in commercial farming and } \\
\text { processing. } \\
\text {-Inadequate availability of quality agricultural } \\
\text { inputs. } \\
\text {-Inadequate availability of extension services. } \\
\text {-Lack of organized marketing system. } \\
\text {-Low bargaining power of farmers. } \\
\text {-Few farmers' associations (i.e. AMCOSs) } \\
\text {-Inadequate credit facilities. }\end{array}$ & $\begin{array}{l}\text { District Executive Directors (DEDs); } \\
\text { District Agricultural, Irrigation, and } \\
\text { Cooperative Officers (DAICOs); District } \\
\text { Trade Officers (DTOs); farmers, } \\
\text { /Agricultural Marketing Co-operative } \\
\text { Societies (AMCOs); producer groups; } \\
\text { Financial Institutions, VICOBAs; Officers } \\
\text { of Tanzania Chamber of Commerce, } \\
\text { Industry and Agriculture (TCCIA); } \\
\text { Development partners such as }\end{array}$ \\
\hline Milling & $\begin{array}{l}\text {-In adequate electricity. } \\
\text {-Unfair By-laws by the LGAs. }\end{array}$ & $\begin{array}{l}\text { District Executive Directors (DEDs); LGA } \\
\text { Lawyers; District Trade Officers (DTOs); } \\
\text { Representatives of Milling } \\
\text { Associations/Producer Groups/paddy } \\
\text { distributors; District Officers of Tanzania } \\
\text { Revenue Authority (TRA); District Officers } \\
\text { of Tanzania Electric Supply Company } \\
\text { (TANESCO); District Officers of Tanzania } \\
\text { Chamber of Commerce, Industry and } \\
\text { Agriculture (TCCIA). }\end{array}$ \\
\hline
\end{tabular}

Artisanal and -Presence of many levies and taxes in the Small-scale value chain of the ASM sector.

Mining (ASM) -Poor technology.

-Lack of geological maps.

-Lack of credit facilities.
District Executive Directors (DEDs);

District Mining Officers (DMOs); District Legal Officers (DLOs); District Trade Officers (DTOs); Artisanal and Small-scale Miners (ASM); District Officers of Tanzania Revenue Authority (TRA); Officers from the District Mining Office; District Officers of Tanzania Chamber of Commerce, Industry and Agriculture (TCCIA).

\begin{tabular}{|c|c|c|}
\hline $\begin{array}{l}\text { Livestock } \\
\text { keeping }\end{array}$ & $\begin{array}{l}\text {-Low productivity due to the use of traditional } \\
\text { hybrid. } \\
\text {-Inadequate availability of quality inputs. } \\
\text {-Inadequate availability of extension services. } \\
\text {-Lack of organized marketing system. } \\
\text {-Lack of abattoirs. } \\
\text {-Inadequate credit facilities. }\end{array}$ & 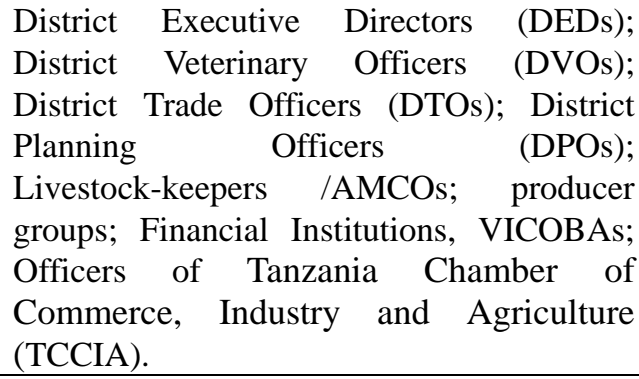 \\
\hline Beekeeping & $\begin{array}{l}\text {-Low productivity due to the use of traditional } \\
\text { beehives } \\
\text {-Inadequate credit facilities } \\
\text {-Deforestation }\end{array}$ & $\begin{array}{l}\text { District Executive Directors (DEDs); } \\
\text { District Bee-keeping Officers (DBOs); } \\
\text { District Trade Officers (DTOs); District } \\
\text { Forest Officers (DFOs; Bee-keepers; } \\
\text { Producer Groups; Financial Institutions, } \\
\text { VICOBAs; Officers of Tanzania Chamber } \\
\text { of Commerce, Industry and Agriculture } \\
\text { (TCCIA). }\end{array}$ \\
\hline
\end{tabular}


Source: Field data

\section{Conclusion}

Instead of self-contained, hierarchical bureaucratic process mediated by more or less democratically elected politicians, the government and other policy makers should seek to involve other actors in the formulation and implementation of economic policies and programmes at local level in the Tanzanian economy. The central government should considerably reduce its responsibility for growth of the local economies. Thus, an effective LED require key stakeholders led by Local Government Authorities (LGAs) to develop and promote entrepreneurial culture; create conducive regulatory environment for local businesses.

\section{Acknowledgement}

The research is financed by BEST-Dialogue.

\section{References}

Addis, Y. (2019). Review on the challenges and opportunities of diary value chain development in Ethiopia. The International Journal of Business Management and Technology, $3(2), 20-28$.

Agranoff, R. (2012). Collaborating to manage: A primer for the public sector. Washington, DC: Georgetown University Press.

Ajay S., \& Micah, M. (2014). Sampling techniques and determination of sample size in applied statics research: An overview. International Journal of Economics Commerce and Management, 2(11), 1-22.

Akudugu, J. A., \& Laube, W. (2013). Implementing Local Economic Development in Ghana: Multiple actors and rationalities (Working Paper No. 113). Bonn, Germany: Centre for Development Research, University of Bonn.

Akpeko, A. (2018). Local Economic Development strategies and challenges: A comparative empirical evidence from Ghana's local governance system. Journal of Public Administration and Governance, 8(40), 110-126. https://doi.org/10.5296/jpag.v8i4.13894

Ansell, C., \& Gash, A. (2018). Collaborative platforms as a governance strategy. Journal of Public Administration Research and Theory, 28(1), 16-32. https://doi.org/10.1093/jopart/mux030

Banyikwa, W. F. (2017). Outcomes of rural-urban Migration in Tanzania. Tanzania Economic Review, 7(2), 7-19.

Barreto, M. L., Schein, P., Hinton, J., \& Hruschka, F. (2018). Economic contributions of Artisanal and Small-scale Mining in Uganda: Gold and clay (Technical Report). Kampala, Uganda: Alliance for Responsible Mining (ARM). Retrieved from www.responsiblemines.org. 
Beguerie, V., \& Palliere, B. (2016). Can rural electrification stimulate the local economy? Constraints and prospects in South-East Mali. Journal of Field Action, (Special Issue), 20-25.

Bjarstig, T. (2017). Does collaboration lead to sustainability? A study of Public-Private Partnerships in the Swedish mountains, Sustainability, 9, 1-22.

Confederation of Tanzania Industries (2017). The State of Counterfeit Goods in Tanzania (Technical Report). Dar es salaam, Tanzania: CTI.

Desta, I., Bishagazi K. P., \& Temesgen, K. (2019). Industry characteristics and voluntary disclosure in private mining and manufacturing firms in Tanzania. Journal of Developing Areas, Tennessee State University, College of Business, 53(3), 141-154. https://doi.org/10.1353/jda.2019.0043

Deus, D. N., Magreth, B., \& William, P. (2014). Trade impediments and market transaction arrangements for maize and rice in Tanzania. World Journal of Social Science Research, 1(1), 413-427. https://doi.org/10.22158/wjssr.v1n1p1

Dickovick, J. T., \& Wunsch, J. S. (2014). Decentralization in Africa: The paradox of state strength. Boulder, Colorado: Lynne Rienner.

Financial Sector Deepening Trust. (2011). AgFiMS Tanzania 2011 Headline Findings (Technical Report). Retrieved from http://www.fsdt.or.tz

Hidayat, N. K., Glasbergen, P., \& Offermans, A. (2015). Sustainability certification and palm oil smallholders' livelihood: A comparison between scheme smallholders and independent smallholders in Indonesia. International Food and Agribusiness Management Review, 18(3), $25-48$.

International Energy Agency. (2018). Annual Report. Paris, France: IEA.

International Monetary Fund. (2018). Annual Report. Washington, DC: IMF.

Isaga, N. (2018). Access to bank credit by smallholder farmers in Tanzania: A case study. AFRIKA FOCUS, 31(1), 241-256. https://doi.org/10.21825/af.v31i1.9048

Jilli, N. N., Masaku, M. M., \& Selepe, B. M. (2017). SMMEs promoting Local Economic Development (LED) in UMlalazi local municipality, KwaZulu-Natal. African Journal of Hospitality, Tourism and Leisure, 6(1), 1-10.

Jovovic, R., Draskovic, M., Delibasic, M., \& Jovovic, M. (2017). The concept of sustainable regional development-institutional aspects, policies, and prospects. Journal of International Studies, 10(2), 255-266. https://doi.org/10.14254/2071-8330.2017/10-1/18

Kacar, B., Curic, J., \& Ikic, S. (2016). Local Economic Development in theories of regional economies and rural studies. Economics of Agriculture, 63(1), 231-246. https://doi.org/10.5937/ekoPolj1601231K

Kamara, R. D. (2017). Creating enhanced capacity for Local Economic Development through collaborative governance in South Africa. Socio Economic Challenges, 1(3), 98-115. https://doi.org/10.21272/sec.1(3).98-115.2017 
Khumalo, P. (2015). Decentralization and Local Economic Development in four southern African countries. Journal of Social Sciences, 45(1), 22-30. https://doi.org/10.1080/09718923.2015.11893483

Lyatuu, E. T., Nie, F., \& Fang, C. (2015). The Role of agriculture in the economic growth and poverty reduction in Tanzania. Journal of Economics and Sustainable Development, 6(14), 154-165.

Lyatuu, P. M., \& Urassa, J. K. (2016). Land access, livelihood strategies and rural household well-being in Mvomero district, Tanzania. Journal of Natural Resources and Development, 6, 46-54. https://doi.org/10.5027/jnrd.v6i0.05

Meyer, D. (2014). Local Economic Development (LED), challenges and solutions: The case of the Northern free state region, South Africa. Mediterranean Journal of Social Sciences, 5(16), 624-634. https://doi.org/10.5901/mjss.2014.v5n16p624

Mutagwaba, W., Tindyebwa, J. B., Makanta, V., Kaballega, D., \& Maeda, G. (2018). Artisanal and Small-scale Mining in Tanzania: Evidence to inform an 'action dialogue' (Research Report). London, UK: IIED. Retrieved from www.pubs.iied.org.

National Bureau of Statistics (2012). 2012 population and housing census: Population distribution by administrative units; key findings. Dar es salaam, Tanzania: NBS

Olomi, R. D., \& Gerwen, F. (2018). Sustainable promotion of Public-Private sector dialogue in rural areas: The case of Tanzania (Technical Report). Dar es Salaam, Tanzania: SNV.

Owani, J., \& Mukuye, R. (2018). Local Economic Development for equitable growth in Gulu and Mbale Municipalities (Technical Report). Kampala, Uganda. UNCDF.

Parilla, J., \& Liu, S. (2018). Examining the local value of economic development incentives: Evidence from four US Cities (Technical Report). Brookings, USA: Metropolitan Policy Program (MPP).

Pike, A., Marlow, D., McCarthy, A., O’Brien, P., \& Tomaney, J. (2014). Local institutions and Local Economic Development: The local enterprise partnerships in England, 2010. Cambridge Journal of Regions, Economy and Society, 8, 185-204. https://doi.org/10.1093/cjres/rsu030

Prasanna, R. I. R., \& Shiratake, Y. (2014). Sustainability of resources: Dairy sector dual circulation system under market liberalization- A case study of the dairy sector in the Kurunegala District, Srilanka. Agroecology and Sustainable Food Systems, 38(1), 109-133. https://doi.org/10.1080/21683565.2013.763318

Rickman, D., \& Wang, H. (2019). US state and local fiscal policy and economic activity: Do we know more now? Journal of Economic Surveys, https://doi.org/10.1111/joes.12316.

Rogerson, C. M. (2011). Tracking Local Economic Development policy and practice in South Africa, 1994-2009. Urban Forum, 22(2), 149-168. https://doi.org/10.1007/s12132-011-9113-1 


\section{Macrothink}

Journal of Public Administration and Governance ISSN 2161-7104 2021, Vol. 11, No. 2

Rogerson, C. M., \& Nel, E. (2016). Planning for Local Economic Development in spaces of despair: Key trends in South Africa's 'distressed areas. Local Economy, 31(1-2), 124-141. https://doi.org/10.1177/0269094215623731

SeedCLIR (2014). SeedCLIR Tanzania 2014 (Pilot Report). USAID

Selmeczi, A. (2015). Haunted by the rebellion of the poor: Civil society and the racialized problem of the (non-) economic subject. Faucault Studies, 20, 52-75. https://doi.org/10.22439/fs.v0i0.4929

Sosy, J. J. (2013). Socio-economic constraints among local artisanal miners in Simanjiro District, Tanzania (Unpublished master's thesis). Sokoine University of Agriculture, Morogoro, Tanzania.

Srithongrung, A., \& Sanchez-Juarez, I. (2015). Fiscal policies and subnational economic growth in Mexico. International Journal of Economics and Financial Issues, 5(1), 11-22.

Torero, M. (2015). The impact of rural electrification: Challenges and ways forward. Paper presented at the $11^{\text {th }}$ Conference AFD PROPARCO/EUDN: Energy for Development, Paris, France. https://doi.org/10.3917/edd.hs03.0049

United Republic of Tanzania. (2015). The Tanzania's National Five-Year Development Plan 2016/2017-2020/2021: Nurturing Industrialization for Economic Transformation and Human Development. Dar es Salaam, Tanzania: Government Printers.

World Bank. (2018). Annual Report. Washington, DC: WB.

Wwuyts, M., \& Kilama, B. (2014). Economic transformation in Tanzania: Vicious or virtuous circle? (Working Paper 14/4). REPOA.

Yamane, T. (1967). Statistics: An introductory analysis. (2 ${ }^{\text {nd }}$ Edition). New York: Harper and Row.

Zvarivadza, T. (2014, October). Artisanal and Small-scale Mining as a challenge and possible contributor to sustainable development. In Fourie A.B, Tibbett M, Weiersbye, I.M, \& Dye, P.J (Eds.), $9^{\text {th }}$ international conference on Mine Closure Conference (pp. 1-17). Johannesburg, South Africa: Australian Centre for Geomechanics.

\section{Copyright Disclaimer}

Copyright for this article is retained by the author(s), with first publication rights granted to the journal.

This is an open-access article distributed under the terms and conditions of the Creative Commons Attribution license (http://creativecommons.org/licenses/by/4.0/). 